\title{
Biomphalaria subprona (Martens, 1899) (Gastropoda: Planorbidae)
}

\section{W Lobato Paraense}

Departamento de Malacologia, Instituto Oswaldo Cruz, Av. Brasil 4365, 21045-900 Rio de Janeiro, RJ, Brasil

A description is given of the shell, head-foot, pulmonary wall, reproductive system and radula of Biomphalaria subprona (Martens, 1899). A diagnosis between it and two other congeneric species under $10 \mathrm{~mm}$ in shell diameter occurring in Middle America (Biomphalaria helophila and B. schrammi) is presented.

Key words: Biomphalaria subprona - Biomphalaria helophila - Biomphalaria schrammi - morphology taxonomy - Guatemala

This planorbid snail was described by Martens (1899 : 396-397) as follows:

19. Planorbis subpronus, sp.n. (Tab. XXI.fig. 15.)

Testa subinflata, solidula, confertim striatula, obscure cornea, latere dextro profunde, sinistro mediocriter spiratim excavato, utraque excavatione subangulatim cincta, peripheria rotundata; anfr. 31/2, celeriter crescentes, ultimus prope aperturam sensim descendens; apertura valde obliqua, semiovata, margine dextro leviter descendente, externo et sinistro bene arcuatis, columellari distincto, brevi, obliquo; paries aperturalis parum convexus, callo tenui textus.

Diam. maj. 5, min. 4 , alt. 2 ; apert. diam. 21/2, ampl. 2 millim.

Hab. S.E. Mexico: Amatitan, State of Tabasco (Conradt, in Mus. Berol.).

Allied to P. pronus, v. Mart. [Binnen-Mollusken v. Venezuela, p. 42, t. 2.Fig. 5 (1873)], but smaller, without spiral furrows, and with the last whorl less expanded at the aperture. In both species the width of the aperture does not exceed the absolute breadth (height) of the whole shell, although the aperture is very oblique, owing to its right margin deviating considerably to the left side.

As this species somewhat resembles $P$. obstructus, I have broken up a specimen and ascertained that there are no internal teeth present.

As far as I know, P. subpronus is unknown anatomically.

\section{MATERIALS AND METHODS}

This study is based on a sample of 28 specimens collected in August 1976 from Lake Amatitlán ( $\left.14^{\circ} 27^{\prime} \mathrm{N}, 90^{\circ} 34^{\prime} \mathrm{W}\right)$, about $15 \mathrm{~km}$ south of Guatemala City.

Ten specimens to be dissected were relaxed overnight in aqueous solution of $0.05 \%$ nembutal.Then they were immersed for $40 \mathrm{sec}$ in

CNPq Research Fellow. Fax: 55-21-280.5840

Received 11 September 1995

Accepted 9 October 1995 water heated at $70^{\circ} \mathrm{C}$, from which they were transferred to water at room temperature. While under water the animals were drawn from the shell with a small forceps applied to the cephalopedal mass, and fixed in slightly modified Railliet-Henry's fluid (distilled water $930 \mathrm{ml}$, sodium chloride $6 \mathrm{~g}$, formalin $50 \mathrm{ml}$, glacial acetic acid $20 \mathrm{ml}$ ). The radulae were separated from the buccal mass by digestion for $12 \mathrm{hr}$ in a solution of $\mathrm{NaOH}$ at $56^{\circ} \mathrm{C}$. They were then rinsed in tap water and mounted in a drop of glycerin on a microscope slide, with the dorsal (toothed) surface upwards as in the living animal. Measurements were made on camera lucida drawings.

Voucher specimens are deposited in the malacological collection of Instituto Oswaldo Cruz (CMIOC-2305).

\section{DESCRIPTION}

Shell - The largest shell (Fig. 1) is $5 \mathrm{~mm}$ in diameter, $2 \mathrm{~mm}$ in width at the aperture $(1.5 \mathrm{~mm}$ at the beginning of the body whorl), and has 3.5 whorls.

The shell is thin, light horn in color, lustrous, somewhat translucent, sculptured with marked lines of growth. The whorls, delimited by deep sutures, increase rapidly in width; on the right side the body whorl is about twice as wide at the aperture as at its beginning, and on the left side it is about four times as wide. The whorls are subangular on both sides, more pronouncedly on the left; on the right side the body whorl gradually gets roundish as it approaches the apertural region. The inner whorl is clearly visible on both sides, at the bottom of a deep funnel-like depression that is wider on the left. The periphery is rounded. The aperture is broadly sublunate, somewhat deflected to the left in some specimens. The peristome is thin and sharp; there is a tenuous callus on the parietal wall. There are no apertural lamellae.

Head-foot and pulmonary wall - The cephalo- 


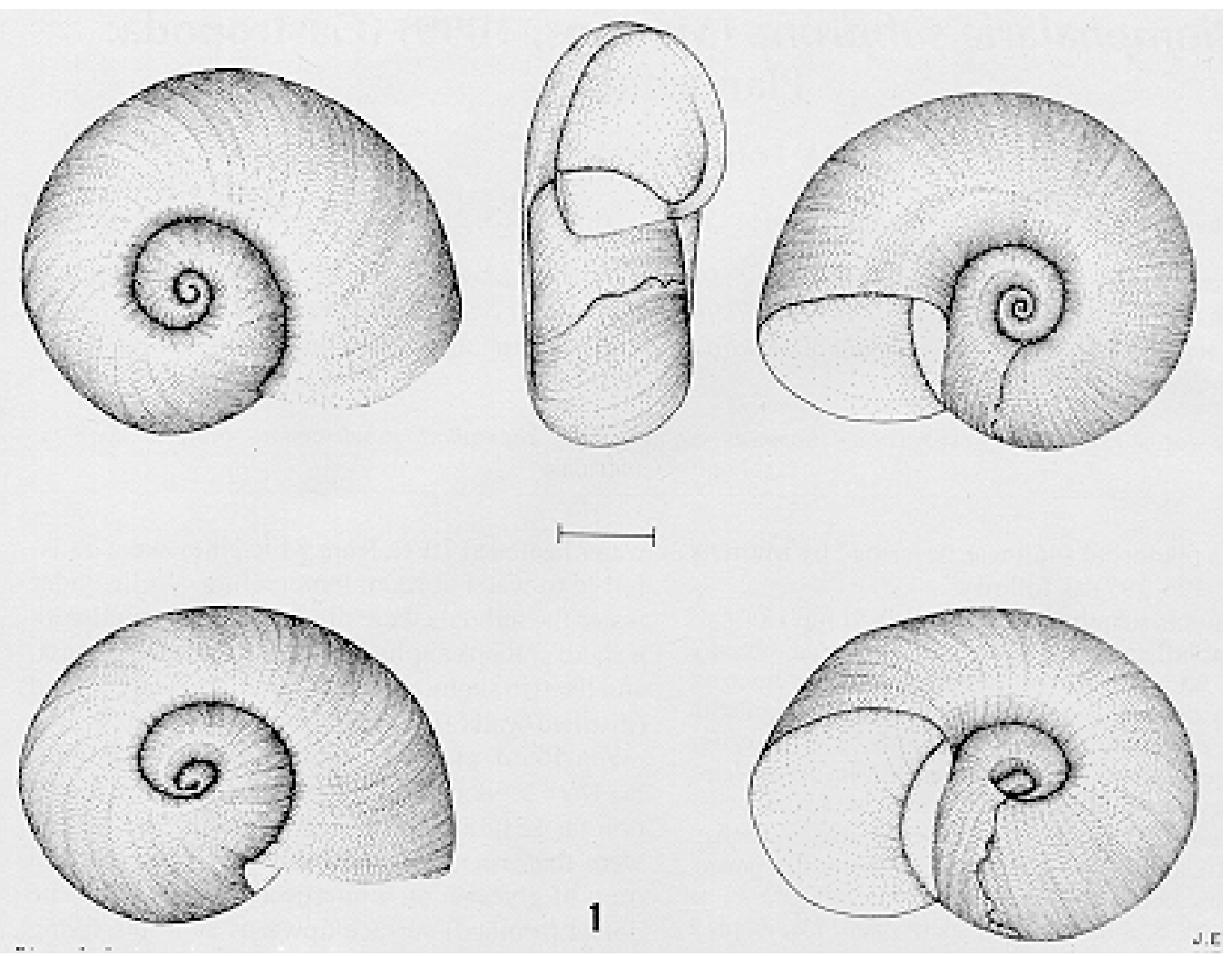

Biomphalaria subprona from Lake Amatitlán, Guatemala. Fig. 1: shell of largest specimen. Bar = $1 \mathrm{~mm}$.

pedal mass is diffusely brownish gray. A narrow melanic stripe parallels the mantle collar, and another wider stripe runs along the insertion of the septum that separates the hypopeplar and pulmonary cavities. The roof of the pulmonary cavity is blotched with black. There is no renal ridge.

Reproductive system - (Fig. 2) - The ovotestis (ot) is composed of about 30 diverticula, most of which are unbranched. A minutely dissected ovotestis had 29 diverticula, of which 23 were simple and 6 bifurcate. The ovispermiduct (od) and the seminal vesicle (sv) show no special features; the latter is beset with well-developed diverticula varying in shape from knoblike to fingerlike.

The oviduct (ov) is tortuous and very short, opening into a large oviducal pouch (op). The nidamental gland (ng) has no taxonomically significant characteristics. The vagina (va) is short and shows on its ventral wall a poorly developed swelling, the vaginal pouch (Figs 3, 4, vp), usually masked by a thin fibrous membrane. The spermatheca (sp) is obovoid, somewhat elongate, showing some variation in shape with the amount of its contents; the spermathecal duct is about half as long as the body. The caudal portion of the female duct (from the carrefour to the middle of the oviducal pouch) is about half as long as the cephalic portion (from the middle of the oviducal pouch to the vaginal opening), the ratio between their lengths (caudal : cephalic) varying from 0.45 to 0.70 . The ratio between the lengths of the cephalic portion and of the penial complex varies from 0.70 to 0.83 .

The spermiduct (sd) follows a tortuous course adnate to the oviduct and, while or after traversing the dorsal groove of the oviducal pouch, gives off a series of 6-11 prostatic diverticula. Owing to the large size of the oviducal pouch, its groove usually lodges some caudal diverticula, sometimes concealing the posterior half of the prostate gland (pr). The prostatic diverticula (Fig. 5) are rather thick, packed tightly together, sometimes unbranched, oftenest bi- or trifurcate.The foremost diverticulum is usually inserted between the nidamental gland and the spermathecal body, but in some instances it partially covers the latter. The penis sheath (ps) is uniformly cylindric; it is shorter than the prepuce (pp) and at least half as wide. The ratio between the lengths of the penis sheath and the prepuce varies from 0.50 to 0.67 . The penial complex (penis sheath plus prepuce) is just a little shorter than the whole female duct; the ratio female duct to penial complex varies from 1.01 to 1.30. The penis, about as long as the penis sheath, tapers to a point where is the outlet of the penis 
canal. Histologically it shows a well-developed erectile tissue surrounding the penis canal and enveloped by a double muscular coat, of which the inner layer is longitudinal and the outer one circular, the whole invested by the outer epithelium. As usual with Biomphalaria, there are two main extrinsic muscles inserted into the cephalic end of the penis sheath, at its junction with the prepuce: a retractor (rm) arising from the columellar muscle, and a protractor $(\mathrm{pm})$ connected with the head wall. A variable number of secondary retractor and protractor muscles are attached to the preputial wall.

Radula - In the largest specimen there are 115 transverse rows of teeth, with the formula 18-1-18 (5 laterals, 4 intermediates, 9 marginals). Radular teeth are shown in Fig. 6.

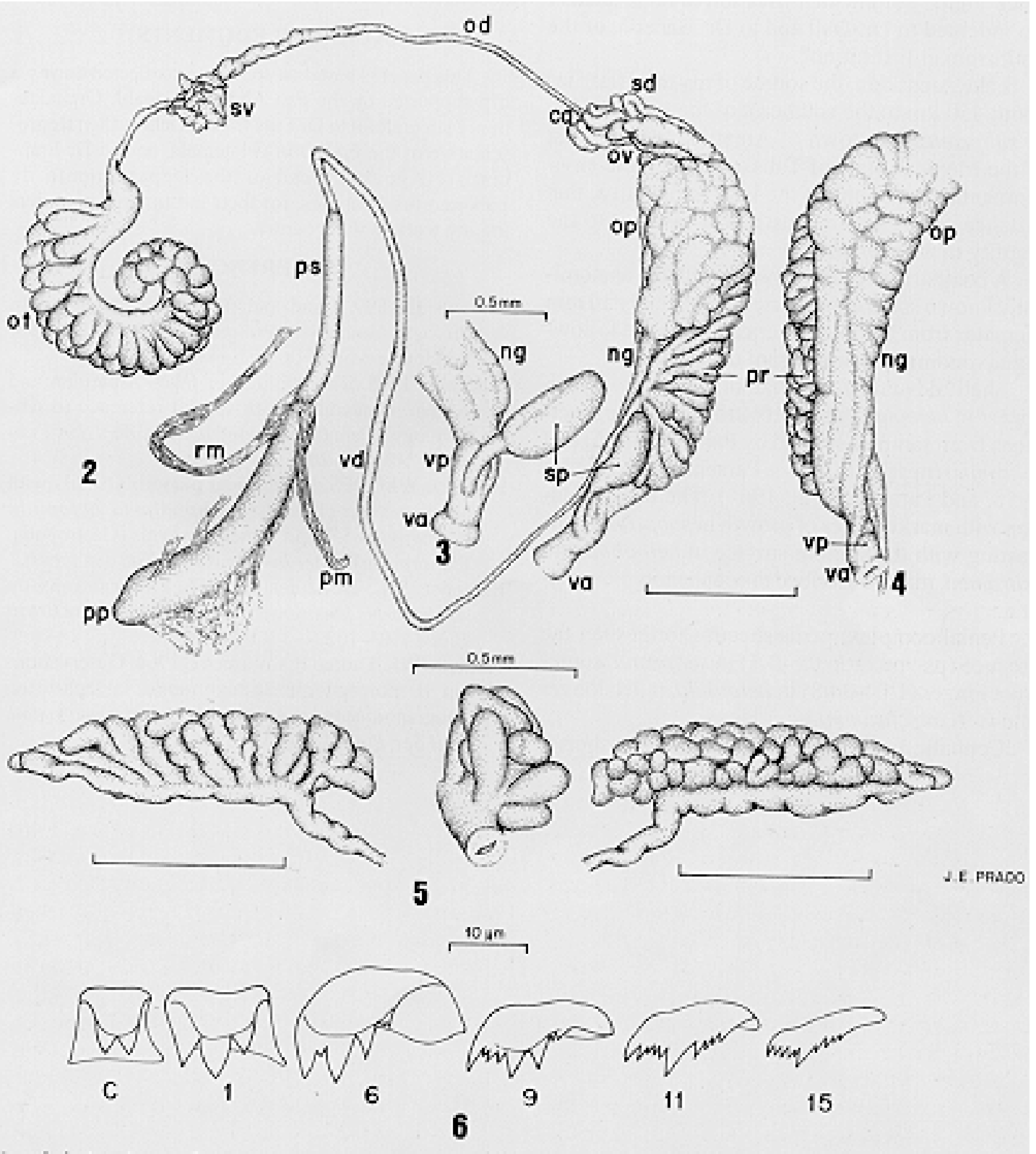

Biomphalaria subprona from lake Amatitlán, Guatemala. Fig. 2: reproductive system. Fig. 3: vaginal complex. Fig. 4: cephalic portion of female duct, left side. Fig. 5: prostate gland, right side (left), interproximal aspect (center), left side (right).ca $=$ carrefour, $\mathrm{ng}=$ nidamental gland, od $=$ distal segment of ovispermiduct, $\mathrm{op}=$ oviducal pouch, ot $=$ ovotestis, ov $=$ oviduct, $\mathrm{pm}$ $=$ protractor muscle of penial complex, $\mathrm{pp}=$ prepuce, $\mathrm{pr}=$ prostate, $\mathrm{ps}=$ penis sheath, $\mathrm{rm}=$ retractor muscle of penial complex, $\mathrm{sd}=$ spermiduct, $\mathrm{sp}=$ spermatheca, $\mathrm{sv}=$ seminal vesicle, $\mathrm{va}=$ vagina, $\mathrm{vd}=$ vas deferens, $\mathrm{vp}=$ vaginal pouch. Fig. $6:$ radular teeth; numbers indicate position in transverse row.c $=$ central, $1=$ lateral, $6=$ intermediate, $9,11,15=$ marginals. Bar $=1 \mathrm{~mm}$ (except Figs 3, 5 center, 6). 


\section{REMARKS}

A survey of the descriptions of Neotropical planorbids led me to conclude that the present species best corresponds with that of Planorbis subpronus. It was previously collected from Lake Amatitlán by Meek (1908), who referred to it as follows: "Planorbis subpronus Von Martens. Very small, rather common. Of no economic importance", and "For the identification of these shells I am indebted to Dr. Dall and to Dr. Bartsch, of the Smithsonian Institution".

Lake Amatitlán, the source of my material, lies about $450 \mathrm{~km}$ to the southeast of the type locality of subpronus, the town of Amatitan, on the west of the Mexican state of Tabasco. Given the environmental conditions of the intervening area, that distance seems not to constitute a restraint to the vagility of Biomphalaria.

A comparison of B. subprona with the anatomically known small congeneric species under $10 \mathrm{~mm}$ diameter from Middle America shows the following taxonomically significant differences.

Shell: devoid of lamellae in subprona, which appear in helophila (about $10 \%$ to $90 \%$ of the specimens from samples studied by Paraense 1966) and schrammi (nearly $100 \%$, see Paraense \& Deslandes 1956, and Paraense et al. 1964). The ornamentation with marked lines of growth in subprona, contrasting with the smooth surface in helophila and schrammi, may be ascribed to ecophenotypic variation.

Penial complex: penis sheath shorter than the prepuce (ps : pp ratio $0.5-0.7$ ) in subprona, somewhat longer (1.04-2.08) in helophila, much longer (4.0-8.0) in schrammi.

Cephalic portion of the female duct: shorter than the penial complex (cp : pc ratio 0.7-0.8) in subprona, much longer (2.7-4.6) in helophila, only a little longer (1.1-1.7) in schrammi.

Oviducal pouch: comparatively larger in subprona, covering up to half of the prostatic gland, seldom covering the caudalmost prostatic diverticulum in the other two.

Vaginal pouch: poorly developed in subprona, absent in the other two.

\section{ACKNOWLEDGMENTS}

This paper is based on specimens collected during a trip supported by the Pan American Health Organization. I am grateful to Dr Luís Carlos Ochoa, then Representative of the PAHO in Guatemala, and to Dr Francisco J Aguilar, Head of the Departamento de Laboratorios Centrales, for their inestimable help during my work in that country.

\section{REFERENCES}

Martens E 1899. Land and freshwater mollusca. In Biologia Centrali-Americana. . Taylor \& Francis, London, xxviii + 706 pp.

Meek SE 1908. The zoölogy of lakes Amatitlan and Atitlan, Guatemala, with special reference to ichthyology. Field Columbian Museum, Zoöl Ser, Publ no 127, 7: 159-206.

Paraense WL 1996. Neotropical planorbid snails with apertural lamellae. I. Biomphalaria helophila (Orbigny, 1835) and some synonyms (Gastropoda: Planorbidae). Mem Inst Oswaldo Cruz (in press).

Paraense WL, Delandes N 1956. Observations on Australorbis janeirensis (Clessin, 1884). Rev Brasil Biol 16: 81-102.

Paraense WL, Fauran P, Courmes E 1964. Observations sur la morphologie, la taxonomie, la répartition géographique et les gîtes d'Australorbis schrammi. Bull Soc Pathol Exot 57: 1236-1254. 